\title{
Nine Constituents Including Six Xanthone-Related Compounds Isolated from Two Ascomycetes, Gelasinospora santi-florii and Emericella quadrilineata, Found in a Screening Study Focused on Immunomodulatory Activity
}

\author{
Haruhiro FusImoto, ${ }^{*, a}$ Takeshi AsaI, $^{b}$ Yong-Pil KIm, ${ }^{b}$ and Masami IsHIBASHI ${ }^{b}$ \\ ${ }^{a}$ Faculty of Pharmaceutical Sciences, Teikyo Heisei University; 2289-23 Uruido, Ichihara, Chiba 290-0193, Japan: and \\ ${ }^{b}$ Graduate School of Pharmaceutical Sciences, Chiba University; 1-33 Yayoi-cho, Inage-ku, Chiba 263-8522, Japan. \\ Received September 26, 2005; accepted December 22, 2005
}

Five metabolites tentatively called GS-1 (1) - 5 (5) from Gelasinospora santi-florii, and four tentatively called EQ-4 (6), EQ-6 (7)-8 (9) together with 1-4 from Emericella quadrilineata have been isolated in a screening study on immunomodulatory fungal constituents. Among these nine metabolites, EQ-7 and 8 have been unknown. This time, the structures of GS-4 which has previously been isolated, EQ-7, and $\mathbf{- 8}$ have been determined to be $(4 R, 4 \mathrm{a} S, 9 \mathrm{a} R)-1,9 \mathrm{a}-d i h y d r o n i d u l a l i n ~ A ~(4),(4 S, 4 \mathrm{a} R, 9 \mathrm{a} R)-4 \mathrm{a}$-carbomethoxy-1,4,4a,9a-tetrahydro-4,8dihydroxy-6-methylxanthone (8), and 9-hydroxymicroperfuranone (9), respectively, and the six other metabolites have been identified. On bioassay, a dihydroxanthone, nidulalin A (1), a hexaketide, sordarial (5), and a xanthone, pinselin (7) have displayed significant immunosuppressive activities. The structure-activity relationships of these constituents have also been discussed.

Key words immunosuppressive fungal component; Gelasinospora santi-florii; Emericella quadrilineata; Ascomycete; xanthone; hexaketide

In our screening program on immunomodulatory constituents from fungi, many immunosuppressive metabolites have already been isolated from various Ascomycetes belonging to Gelasinospora, Diplogelasinospora, Microascus, Emericella, Eupenicillium, Chaetomium, and Zopfiella and a Fungi Imperfecti belonging to Trichurus. ${ }^{1)}$ Successively, the EtOAc extracts of the two Ascomycetes, Gelasinospora santi-florii CAILLEUX and Emericella quadrilineata (Thom \& RAPER) C. R. BENJAMIN showed appreciably suppressive effects on the proliferation (blastogenesis) of mouse splenic lymphocytes stimulated with the mitogens, concanavalin A (Con A), and lipopolysaccharide (LPS). Repeated chromatographic fractionations of the EtOAc extract of G. santi-florii IFM4514, ${ }^{2)}$ which suppressed the Con A-induced proliferation of mouse splenic lymphocytes by $99.6 \%$ at $50 \mu \mathrm{g} / \mathrm{ml}$, gave five constituents tentatively called GS-1 (1) -5 (5) [yields $(\%)$ of $\mathbf{1}, \mathbf{2}, \mathbf{3}, \mathbf{4}$, and 5 from the EtOAc extract: $0.84,0.14,0.69,0.077$, and 0.52 , respectively].

Meanwhile, the EtOAc extract of E. quadrilineata IFM42027, ${ }^{2)}$ which suppressed the Con A-induced proliferation of mouse splenic lymphocytes by $96.6 \%$ at $50 \mu \mathrm{g} / \mathrm{ml}$, was treated with $n$-hexane to give a defatted extract, suppressing the Con A-induced proliferation $99.7 \%$ at $50 \mu \mathrm{g} / \mathrm{ml}$. Repeated chromatographic fractionations of an EtOAc layer, which was obtained from partition of the defatted extract with EtOAc- $\mathrm{H}_{2} \mathrm{O}(3: 1, \mathrm{v} / \mathrm{v})$, gave eight constituents tentatively called EQ-1-8. The fact that EQ-1, 2, 3, and 5 were identical with $3,2,4$, and $\mathbf{1}$, respectively, on the ${ }^{1} \mathrm{H}$ - and ${ }^{13} \mathrm{C}$ NMR spectra, TLC behaviors, and specific rotations unified the names EQ-1, 2, 3, and 5 with the names GS-3, 2, 4, and 1, respectively. The eight constituents GS-3 (3), 2 (2), 4 (4), 1 (1), and EQ-4 (6), 6 (7) -8 (9) were obtained from E. quadrilineata in the following yields [yields (\%) of 3, 2, 4, 1, 6, 7, 8, and 9 from the EtOAc extract: $0.060,1.3,0.51,1.1$, $0.77,0.15,0.089$, and 0.025 , respectively]. Among the nine constituents $\mathbf{1}-\mathbf{9}$ from the two fungi, $\mathbf{1}, \mathbf{5}$, and $\mathbf{7}$ showed sig- nificantly immunosuppressive activity $\left(\mathrm{IC}_{50}\right.$ value of $\mathbf{1}, \mathbf{5}$, and 7 against the Con A-induced proliferation: 0.15, 6.5, and $5.1 \mu \mathrm{g} / \mathrm{ml}$, respectively). This paper deals with the structures and immunosuppressive activities of the nine constituents $1-9$ from the two fungi, among which we briefly reported on the structures and immunosuppressive activities of $\mathbf{1}-\mathbf{5}$ in $1998{ }^{3)}$

GS-1 and 2 were identified with a dihydroxanthone, nidulalin A (1) and a benzophenone, nidulalin B (2) from the Ascomycete, Emericella nidulans var. lata, ${ }^{4)}$ by direct comparison with the authentic specimen and comparison with the ${ }^{1} \mathrm{H}$ - and ${ }^{13} \mathrm{C}$-NMR spectra, respectively. GS-3 was identified with 1-hydroxy-3-methylxanthone (3), a xanthone from an Ascomycete, Anixiella (=Gelasinospora) micropertus $a,{ }^{5)}$ by the ${ }^{1} \mathrm{H}$ - and ${ }^{13} \mathrm{C}$-NMR spectra. GS-5 was identified with sordarial (5), a hexaketide from some Ascomycetes, Sordaria macrospora, ${ }^{6}$ Gelasinospora heterospora, and $G$. longispora, ${ }^{7)}$ by the ${ }^{1} \mathrm{H}$ - and ${ }^{13} \mathrm{C}$-NMR spectra and the specific rotation. EQ-4 was identified with the racemic form of microperfuranone (6), a furanone from $G$. micropertus $a^{5}{ }^{5}$ by the ${ }^{1} \mathrm{H}$ - and ${ }^{13} \mathrm{C}$-NMR spectra and the specific rotation $\left( \pm 0^{\circ}\right)$. EQ-6 was identified with pinselin (7), a xanthone from the Ascomycete, Talaromyces bacillosporus ${ }^{8)}$ by direct comparison with the authentic specimen. To study the structure-activity relationship, 7 was methylated with (trimethylsilyl)diazomethane to give 2-methoxy derivative (10), ${ }^{1} \mathrm{H}-\mathrm{NMR}$ : $\delta$ $4.03(3 \mathrm{H}, \mathrm{s})$.

GS-4 (4), obtained as an optically active white powder $\left([\alpha]_{\mathrm{D}}^{25}-347.2^{\circ}\right)$, gave $\mathrm{C}_{16} \mathrm{H}_{16} \mathrm{O}_{6}$ as the molecular formula. These physicochemical data and the ${ }^{1} \mathrm{H}$ - and ${ }^{13} \mathrm{C}$-NMR data including the two dimensional ${ }^{1} \mathrm{H}-{ }^{1} \mathrm{H}$ shift correlation (COSY), ${ }^{1} \mathrm{H}$-detected heteronuclear correlation through multiple quantum coherence (HMQC), and ${ }^{1} \mathrm{H}$-detected heteronuclear multiple-bond correlation (HMBC) NMR data of 4 indicated that $\mathbf{4}$ was identical with 1,9a-dihydronidulalin A which was originally isolated from $G$. micropertusa, and 
Table 1. ${ }^{1} \mathrm{H}$ - and ${ }^{13} \mathrm{C}-\mathrm{NMR}$ Data for GS-1 (1), GS-4 (4), EQ-7 (8), (R)-MTPA Ester of $8(\mathbf{1 1})$, and $(S)$-MTPA Ester of $8(\mathbf{1 2})$, and $\Delta \delta$ Value $\left(\delta_{12}-\delta_{11}\right)$ in $\mathrm{CDCl}_{3}, \delta(\mathrm{ppm})$ from TMS as an Internal Standard

\begin{tabular}{|c|c|c|c|c|c|c|c|c|c|}
\hline \multirow{2}{*}{ Position } & \multicolumn{2}{|c|}{1} & \multicolumn{2}{|l|}{4} & \multicolumn{2}{|l|}{8} & \multirow{2}{*}{$\frac{11}{\delta_{\mathrm{H}}}$} & \multirow{2}{*}{$\frac{12}{\delta_{\mathrm{H}}}$} & \multirow{2}{*}{$\frac{\Delta \delta \text { value }}{\left(\delta_{12}-\delta_{11}\right)}$} \\
\hline & $\delta_{\mathrm{H}}$ & $\delta_{\mathrm{C}}$ & $\delta_{\mathrm{H}}$ & $\delta_{\mathrm{C}}$ & $\delta_{\mathrm{H}}$ & $\delta_{\mathrm{C}}$ & & & \\
\hline 1 & $\begin{array}{l}7.34(\mathrm{dd}, \\
4.5,2.1)\end{array}$ & 131.7 (d) & $2.64(\mathrm{~m})$ & $24.5(\mathrm{t})$ & $2.47(2 \mathrm{H}, \mathrm{m})$ & $25.6(\mathrm{t})$ & $2.625(\mathrm{~m})$ & $2.630(\mathrm{~m})$ & 0.005 \\
\hline & & & $2.73(\mathrm{~m})$ & & & & $2.725(\mathrm{~m})$ & $2.725(\mathrm{~m})$ & 0 \\
\hline 2 & $6.40^{a)}$ & 126.5 (d) & $6.04(\mathrm{~m})$ & 132.5 (d) & $5.89(\mathrm{~m})$ & 127.4 (d) & $6.053(\mathrm{~m})$ & $6.050(\mathrm{~m})$ & -0.003 \\
\hline 3 & $6.40^{a)}$ & $131.6(d)$ & $5.86(\mathrm{~m})$ & 123.7 (d) & $5.73(\mathrm{~m})$ & $127.3(d)$ & $5.848(\mathrm{~m})$ & $5.845(\mathrm{~m})$ & -0.003 \\
\hline 4 & $4.67(\mathrm{~d}, 5.5)$ & $65.2(\mathrm{~d})$ & $4.66(\mathrm{~d}, 5.9)$ & 66.0 (d) & $4.55(\mathrm{~d}, 8.9)$ & $69.3(\mathrm{~d})$ & $4.650(\mathrm{~d}, 7.8)$ & $4.652(\mathrm{~d}, 5.7)$ & 0.002 \\
\hline $4 \mathrm{a}$ & & $82.9(\mathrm{~s})$ & & $85.2(\mathrm{~s})$ & & $82.7(\mathrm{~s})$ & & & \\
\hline $\mathrm{COOCH}_{3}-4 \mathrm{a}$ & & $168.8(\mathrm{~s})$ & & $168.3(\mathrm{~s})$ & & 170.7 (s) & & & \\
\hline $\mathrm{COOCH}{ }_{3}-4 \mathrm{a}$ & $3.62(3 \mathrm{H}, \mathrm{s})$ & $53.4(q)$ & $3.62(3 \mathrm{H}, \mathrm{s})$ & $52.9(\mathrm{q})$ & $3.71(3 \mathrm{H}, \mathrm{s})$ & $53.4(q)$ & $3.621(3 \mathrm{H}, \mathrm{s})$ & $3.622(3 \mathrm{H}, \mathrm{s})$ & 0.001 \\
\hline 5 & 6.33 (brs) & 108.3 (d) & $6.27(\mathrm{~s})$ & 108.0 (d) & $6.42(\mathrm{~s})$ & 108.4 (d) & $6.338(\mathrm{~s})$ & $6.339(\mathrm{~s})$ & 0.001 \\
\hline 6 & & $151.0(\mathrm{~s})$ & & $149.8(\mathrm{~s})$ & & $151.1(\mathrm{~s})$ & & & \\
\hline$\underline{\mathrm{CH}}_{3}-6$ & $2.28(3 \mathrm{H}, \mathrm{s})$ & $22.6(q)$ & $2.26(3 \mathrm{H}, \mathrm{s})$ & $22.4(q)$ & $2.29(3 \mathrm{H}, \mathrm{s})$ & $22.6(q)$ & $2.240(3 \mathrm{H}, \mathrm{s})$ & $2.241(3 \mathrm{H}, \mathrm{s})$ & 0.001 \\
\hline 7 & $6.40^{a)}$ & 111.4 (d) & $6.36(\mathrm{~s})$ & $111.2(\mathrm{~d})$ & $6.36(\mathrm{~s})$ & 111.1 (d) & $6.250(\mathrm{~s})$ & $6.251(\mathrm{~s})$ & 0.001 \\
\hline 8 & & $162.8(\mathrm{~s})$ & & $161.3(\mathrm{~s})$ & & $162.5(\mathrm{~s})$ & & & \\
\hline $\mathrm{OH}-8$ & $12.10(\mathrm{~s})$ & & $11.50(\mathrm{~s})$ & & $11.30(\mathrm{~s})$ & & $11.577(\mathrm{~s})$ & $11.578(\mathrm{~s})$ & 0.001 \\
\hline $8 \mathrm{a}$ & & $105.7(\mathrm{~s})$ & & $105.1(\mathrm{~s})$ & & $103.6(\mathrm{~s})$ & & & \\
\hline 9 & & $182.8(\mathrm{~s})$ & & 197.7 (s) & & $197.1(\mathrm{~s})$ & & & \\
\hline $9 \mathrm{a}$ & & $127.1(\mathrm{~s})$ & $3.62(\mathrm{~m})$ & $40.3(\mathrm{~d})$ & $\begin{array}{c}3.27(\mathrm{dd}, \\
10.7,7.3)\end{array}$ & $45.2(d)$ & $3.602(\mathrm{~m})$ & $3.605(\mathrm{~m})$ & 0.003 \\
\hline $10 \mathrm{a}$ & & $158.0(\mathrm{~s})$ & & $157.6(\mathrm{~s})$ & & $159.0(\mathrm{~s})$ & & & \\
\hline
\end{tabular}

Multiplicities and coupling constants (in $\mathrm{Hz}$ ) in parenseses. a) Overlapped.

whose relative configuration between $\mathrm{COOCH}_{3}-4 \mathrm{a}$ and $\mathrm{H}-9 \mathrm{a}$ was elucidated to be trans by the differential nuclear Overhauser (DifNOE) experiment in 1998..$^{5}$ ) This time, the absolute structure of GS-4 was finally determined to be $(4 R, 4 \mathrm{a} S, 9 \mathrm{a} R)-1,9 \mathrm{a}$-dihydronidulalin $\mathrm{A}(4)$ by the fact that GS-4 was derived from nidulalin A (1), whose absolute configurations at positions 4 and $4 \mathrm{a}$ were $(R)$ and $(S)$, respectively, ${ }^{4}$ on hydrogenation with $\mathrm{NaBH}_{4}$ in EtOH (this result was briefly reported by us in $1998^{3)}$ ). The fact that the specific rotation and the circular dichroism (CD) curve of $\mathbf{4}$ were similar to those of $\mathbf{1}$ suggested that the absolute configurations at positions 4 and $4 \mathrm{a}$ in 4 were important for the appearance of the optical activity of $\mathbf{4}$ (see Experimental). Compound $\mathbf{4}$ was later synthesized by Tsuji and colleagues in 1999.9)

EQ-7 (8), obtained as an optically active white powder $\left([\alpha]_{D}^{25}+31.4^{\circ}\right)$, gave $\mathrm{C}_{16} \mathrm{H}_{16} \mathrm{O}_{6}$ as the molecular formula, the same as that of 4 . The ${ }^{1} \mathrm{H}$ - and ${ }^{13} \mathrm{C}-\mathrm{NMR}$ data of $\mathbf{8}$ was similar to those of 4 except that the signals of $\mathrm{H}-4[\delta 4.55$ $(\mathrm{d}, J=8.9 \mathrm{~Hz})], \mathrm{C}-4[\delta 69.3(\mathrm{~d})]$, and C-4a $[\delta 82.7(\mathrm{~s})]$ in 8 were different from those of $\mathrm{H}-4[\delta 4.66(\mathrm{~d}, J=5.9 \mathrm{~Hz})], \mathrm{C}-4$ $[\delta 66.0(\mathrm{~d})]$, and C-4a $[\delta 85.2(\mathrm{~s})]$ in 4 ; this suggested that 8 might be a new stereoisomer of $\mathbf{4}$ (see Table 1). Contrary to the fact that the specific rotation and the CD curve of $\mathbf{4}$ were similar to those of $\mathbf{1}$, the specific rotation and the $\mathrm{CD}$ curve of 8 were quite different from those of both 1 and 4 , suggesting that the absolute configurations at positions 4 and $4 \mathrm{a}$ in $\mathbf{8}$ might be different from those in $\mathbf{1}$ and $\mathbf{4}$ (see Experimental). On treatment with $(S)-(+)-$ and $(R)-(-)-\alpha$-methoxy- $\alpha$ (trifluoromethyl)phenylacetyl chloride [(S)- and (R)-MTPA chloride] in pyridine, the hydroxyl at position 4 in $\mathbf{8}$ was esterified to give $(R)$ - and $(S)$-MTPA esters of 8 (11 and 12), respectively. To apply the modified Mosher's method ${ }^{10)}$ to $\mathbf{8}$, the $\Delta \delta$ values $\left(\delta_{12}-\delta_{11}\right)$ were calculated as shown in Table 1, indicating that the absolute configuration at position 4 in $\mathbf{8}$ was $(S)$. In the DifNOE experiment, 1.2, 6.3, and $1.9 \%$ of
NOEs were observed between $\mathrm{H}-4$ and $\mathrm{COOCH}_{3}-4 \mathrm{a}$, between $\mathrm{H}-4$ and $\mathrm{H}-9 \mathrm{a}$, and between $\mathrm{COOCH}_{3}-4 \mathrm{a}$ and $\mathrm{H}-9 \mathrm{a}$, respectively, indicating that $\mathrm{COOC} \underline{H}_{3}-4 \mathrm{a}$ was located at the cis sides of both H-4 and H-9a in 8. Thus, the absolute configurations at positions $4 \mathrm{a}$ and $9 \mathrm{a}$ in $\mathbf{8}$ were $(R)$ and $(R)$, respectively. Accordingly, EQ-7 was deduced to be $(4 S, 4 \mathrm{a} R$, 9a $R$ )-4a-carbomethoxy-1,4,4a,9a-tetrahydro-4,8-dihydroxy6-methylxanthone (8), as shown in Fig. 1.

EQ-8 (9), obtained as a white amorphous powder, gave $\mathrm{C}_{17} \mathrm{H}_{14} \mathrm{O}_{4}$ as the molecular formula. Comparison of the molecular formula and the ${ }^{1} \mathrm{H}$ - and ${ }^{13} \mathrm{C}$-NMR data of 9 with those of $\mathbf{6}$ showed that 9 might be a new monohydroxyl derivative of $\mathbf{6}$ (see Table 2). The HMBC NMR experiment of 9 showed that the new hydroxyl group might be present at position 9 in 9 (see Fig. 1). Accordingly, EQ-8 was deduced to be 9-hydroxymicroperfuranone (9), as shown in Fig. 1. This compound was also racemic as well as $\mathbf{6}$, because the specific rotation was $\pm 0^{\circ}$.

The immunosuppressive activities ( $\mathrm{IC}_{50}$ values) of $\mathbf{1 - 7 , 9}$, and 10, and some known immunosuppressants were calculated against Con-A induced ( $\mathrm{T}$ cell) and LPS-induced (B cell) proliferations of mouse splenic lymphocytes, as shown in Table 3. This table shows that $\mathbf{1}$ possessed considerably high immunosuppressive activity, while those of $\mathbf{5}$ and $\mathbf{7}$ were moderate. The fact that the immunosuppressive activities of $\mathbf{4}$ and $\mathbf{8}$ were lower than that of $\mathbf{1}$ suggested that the presence of $\mathrm{C}=\mathrm{C}$ bond between position 1 and $9 \mathrm{a}$ in $\mathbf{1}$ might be important for the appearance of the immunosuppressive activity of $\mathbf{1}$. The fact that the activity of $\mathbf{1 0}$ was lower than that of 7 also suggested that the presence of the free $\mathrm{OH}$ group at position 2 in 7 might be important for the appearance of the activity of 7 . It was already known that the suppressive effects of substituted xanthones against the proliferation of human lymphocytes were ascribable to the positions of substituents on the xanthone nucleus. ${ }^{11)}$ The immunosuppressive activity of $\mathbf{5}$ was also already known. ${ }^{7}$ 


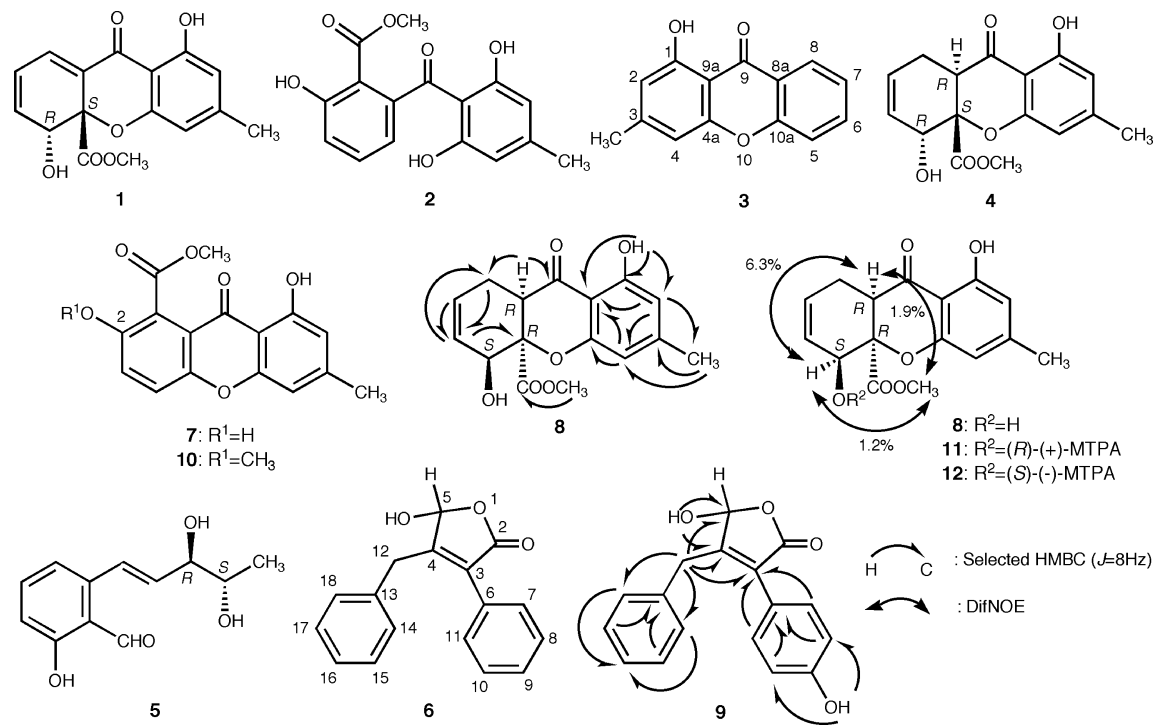

Fig. 1

Table 2. ${ }^{1} \mathrm{H}-$ and ${ }^{13} \mathrm{C}-\mathrm{NMR}$ Data for EQ-4 (6) and EQ-8 (9) in Acetone- $d_{6}$, $\delta(\mathrm{ppm})$ from TMS as an Internal Standard

\begin{tabular}{|c|c|c|c|c|}
\hline \multirow{2}{*}{ Position } & \multicolumn{2}{|c|}{6} & \multicolumn{2}{|c|}{9} \\
\hline & $\delta_{\mathrm{H}}$ & $\delta_{\mathrm{C}}$ & $\delta_{\mathrm{H}}$ & $\delta_{\mathrm{C}}$ \\
\hline 2 & & 170.9 (s) & & $171.2(\mathrm{~s})$ \\
\hline 3 & & $130.8(\mathrm{~s})$ & & $129.8(\mathrm{~s})$ \\
\hline 4 & & $159.6(\mathrm{~s})$ & & $157.5(\mathrm{~s})$ \\
\hline 5 & 5.98 (brs) & 97.7 (d) & $5.91(\mathrm{~d}, 7.8)$ & $97.4(d)$ \\
\hline $\mathrm{OH}-5$ & 6.90 (brs) & & $6.77(\mathrm{~d}, 7.8)$ & \\
\hline 6 & & $130.2(\mathrm{~s})$ & & $121.8(\mathrm{~s})$ \\
\hline 7 & 7.54 (brd, 6.7) & 129.9 (d) & $\begin{array}{l}7.42(\mathrm{ddd}, \\
9.2,2.5,2.5)\end{array}$ & $131.3(\mathrm{~d})$ \\
\hline 8 & $7.46(\mathrm{~m})$ & 129.3 (d) & $\begin{array}{l}6.91(\mathrm{ddd}, \\
9.2,2.5,2.5)\end{array}$ & $116.2(d)$ \\
\hline 9 & $7.43(\mathrm{~m})$ & $129.6(\mathrm{~d})$ & & $158.9(\mathrm{~s})$ \\
\hline $\mathrm{OH}-9$ & & & $8.70(\mathrm{~s})$ & \\
\hline$\overline{10}$ & $7.46(\mathrm{~m})$ & $129.3(d)$ & $\begin{array}{l}6.91(\mathrm{ddd}, \\
9.2,2.5,2.5)\end{array}$ & $116.2(\mathrm{~d})$ \\
\hline 11 & 7.54 (br d, 6.7) & 129.9 (d) & $\begin{array}{l}7.42(\mathrm{ddd}, \\
9.2,2.5,2.5)\end{array}$ & $131.3(\mathrm{~d})$ \\
\hline 12 & $3.97(2 \mathrm{H}, \mathrm{brs})$ & $32.9(\mathrm{t})$ & $\begin{array}{l}3.83(\mathrm{~d}, 15.4) \\
4.11(\mathrm{~d}, 15.4)\end{array}$ & $32.9(\mathrm{t})$ \\
\hline 13 & & $137.5(\mathrm{~s})$ & & $137.8(\mathrm{~s})$ \\
\hline 14 & $7.30(\mathrm{~m})$ & 129.6 (d) & $7.30(\mathrm{~m})$ & 129.6 (d) \\
\hline 15 & $7.26(\mathrm{~m})$ & 129.7 (d) & $7.26(\mathrm{~m})$ & $129.7(d)$ \\
\hline 16 & $7.22(\mathrm{~m})$ & 127.7 (d) & $7.24(\mathrm{~m})$ & $127.6(\mathrm{~d})$ \\
\hline 17 & $7.26(\mathrm{~m})$ & 129.7 (d) & $7.26(\mathrm{~m})$ & 129.7 (d) \\
\hline 18 & $7.30(\mathrm{~m})$ & $129.6(d)$ & $7.30(\mathrm{~m})$ & $129.6(d)$ \\
\hline
\end{tabular}

Multiplicities and coupling constants (in $\mathrm{Hz}$ ) in parentheses.

\section{Experimental}

The general procedures for chemical experiments and other experimental conditions, including those for the evaluation of suppressive activity $\left(\mathrm{IC}_{50}\right.$ values) of samples against the proliferation of mouse splenic lymphocytes stimulated with Con A and LPS, were the same as those described in our previous reports. [This method is based on the formation ratio of MTT-formazan from exogenous 3-(4,5-dimethyl-2-thiazolyl)-2,5-diphenyl-2H-tetrazolium bromide (MTT) in lymphocytes]. ${ }^{1}$ Chemical shifts are expressed in $\delta(\mathrm{ppm})$ values from tetramethylsilane (TMS) as an internal standard.

Isolation of GS-1 (1) - 5 (5) from G. santi-florii IFM4514 G. santiflorii IFM45142) was cultivated on sterilized moistened-rice in Roux flasks $(200 \mathrm{~g} /$ flask $\times 15)$ at $25^{\circ} \mathrm{C}$ for $21 \mathrm{~d}$. The dark brownish moldy-rice was extracted with EtOAc (4.51) with shaking at room temperature for $6 \mathrm{~h}$ three
Table 3. Immunosuppressive Effects of GS-1 (1) - 5 (5), EQ-4 (6), and EQ-6 (7)-8 (9), 2-Methoxy EQ-6 (10), and Azathioprine, Cyclosporin A, and Tacrolimus (FK506) on the Con A-Induced and LPS-Induced Proliferations of Mouse Splenic Lymphocytes

\begin{tabular}{lcc}
\hline \hline \multirow{2}{*}{ Compound } & \multicolumn{2}{c}{$\mathrm{IC}_{50}(\mu \mathrm{g} / \mathrm{ml})$} \\
\cline { 2 - 3 } & Con A-induced & LPS-induced \\
\hline GS-1 (1) & 0.15 & 0.06 \\
GS-2 (2) & $>25$ & 17 \\
GS-3 (3) & $>25$ & $>25$ \\
GS-4 (4) & $>25$ & $>25$ \\
GS-5 (5) & 6.5 & 5.1 \\
EQ-4 (6) & $>25$ & n.t. \\
EQ-6 (7) & 5.1 & 7.4 \\
EQ-7 (8) & $>25$ & $>25$ \\
EQ-8 (9) & $>25$ & n.t. \\
2-Methoxy EQ-6 (10) & $>25$ & $>25$ \\
Azathioprine & 2.7 & 2.7 \\
Cyclosporin A & 0.04 & 0.07 \\
Tacrolimus (FK506) & $1.5 \times 10^{-5}$ & $1.6 \times 10^{-3}$ \\
\hline
\end{tabular}

The $\mathrm{IC}_{50}$ value of each sample was calculated from the correlation curve between the sample concentration (horizontal axis) and the cell proliferation (vertical axis). The curve of each sample was drawn with 7 points, each of which represented the mean of three experiments on each correlation between 7 different concentrations and cell proliferations. n.t.: not tested.

times to give an EtOAc solution ( $c a .13 .51$ ), which gave, after evaporation in vacuo, an EtOAc extract (20.0 g). The extract suppressed the Con A-induced proliferation of mouse splenic lymphocytes $99.6 \%$ at $50 \mu \mathrm{g} / \mathrm{ml}$. The EtOAc extract $(13.0 \mathrm{~g})$ was subjected to chromatography on a silica gel (Wakogel C200, Wako) column with $n$-hexane-EtOAc $(25: 25, \mathrm{v} / \mathrm{v}), n$-hexane-EtOAc$\mathrm{MeOH}(25: 25: 1),(25: 25: 5),(25: 25: 50)$, and $\mathrm{MeOH}$ to give five fractions $1 \mathrm{a}-\mathrm{e}(7.56,2.44,1.20,1.05,0.10 \mathrm{~g})$, respectively. Fraction $1 \mathrm{~b}(1.80 \mathrm{~g})$ was further chromatographed on a silica gel (C60, Nacalai Tesque) column with $n$-hexane-EtOAc $(25: 25),(25: 25), n$-hexane-EtOAc-MeOH $(25$ : $25: 1),(25: 25: 1),(25: 25: 5),(25: 25: 50)$, and $\mathrm{MeOH}$ to give seven fractions $2 \mathrm{a}-\mathrm{g}(11,440,453,379,190,64,23 \mathrm{mg})$, respectively. Fraction $2 \mathrm{c}$ $(100 \mathrm{mg})$ was subjected to preparative TLC on silica gel plates (Kieselgel 60 , Merck) with $\mathrm{CHCl}_{3}$-acetone $(9: 1)$ followed by HPLC on an octadecyl silica gel (ODS) column (Pegasil ODS, Senshu) with $\mathrm{CH}_{3} \mathrm{CN}-\mathrm{H}_{2} \mathrm{O}(1: 1)$ at a flow rate of $8 \mathrm{ml} / \mathrm{min}$ to give $\mathbf{1}(16 \mathrm{mg})$ and $\mathbf{2}(3 \mathrm{mg})$. Fraction $1 \mathrm{a}(7.55 \mathrm{~g})$ was further chromatographed on an ODS (Chromatorex ODS, Fuji-Silysia) column with $\mathrm{MeOH}-\mathrm{H}_{2} \mathrm{O}$ followed by HPLC on an ODS column with $\mathrm{CH}_{3} \mathrm{CN}-\mathrm{H}_{2} \mathrm{O}$ to give $4(10 \mathrm{mg}), \mathbf{3}(90 \mathrm{mg})$, and $\mathbf{1}(10 \mathrm{mg})$. Fraction $2 \mathrm{e}(180$ $\mathrm{mg}$ ) was subjected to preparative TLC on silica gel plates with $\mathrm{CHCl}_{3}$-ace- 
tone $(9: 1)$ to give $\mathbf{5}(50 \mathrm{mg})$.

Isolation of GS-1 (1) - 4 (4), EQ-4 (6), 6 (7), 7 (8), and 8 (9) from $E$. quadrilineata IFM42027 E. quadrilineata IFM420272) was cultivated on sterilized moistened-rice in Roux flasks $(200 \mathrm{~g} /$ flask $\times 3)$ at $25^{\circ} \mathrm{C}$ for $23 \mathrm{~d}$. The dark brownish moldy-rice was extracted with EtOAc (0.91) with shaking at room temperature for $6 \mathrm{~h}$ twice to give an EtOAc extract $(4.47 \mathrm{~g})$, which suppressed the Con A-induced proliferation of mouse splenic lymphocytes by $96.6 \%$ at $50 \mu \mathrm{g} / \mathrm{ml}$. The extract was treated with $n$-hexane $(9.0 \mathrm{ml})$ to give a defatted extract as precipitate $(2.68 \mathrm{~g})$ and a fatty portion as a supernatant. The defatted extract, which suppressed the Con A-induced proliferation by $99.7 \%$ at $50 \mu \mathrm{g} / \mathrm{ml}$, was partitioned with EtOAc- $\mathrm{H}_{2} \mathrm{O}(3: 1)$ (1.21) into an EtOAc layer ( $2.11 \mathrm{~g})$ and an aqueous suspension. The aqueous suspension was further treated with $n-\mathrm{BuOH}-\mathrm{H}_{2} \mathrm{O}(2: 1)$ (1.21) into an $n$-BuOH layer $(162 \mathrm{mg}$ ) and an aqueous layer $(48 \mathrm{mg})$. The EtOAc layer was subjected to chromatography on a silica gel (PSQ-100B, Fuji-Silysia) column with $n$-hexane-EtOAc $(9: 1),(9: 1),(9: 1-4: 1),(2: 1),(2: 1-1: 1)$, $(2: 1-1: 1)$, and EtOAc-MeOH $(1: 1)$ to give seven fractions $1 \mathrm{a}-\mathrm{g}(39$, $296,75,92,200,237,614 \mathrm{mg}$ ), respectively. Fraction 1a was further chromatographed on an ODS (Chromatorex ODS) column with $\mathrm{MeOH}-\mathrm{H}_{2} \mathrm{O}$ $(4: 1)$ to give $3(2.7 \mathrm{mg})$. Fraction $1 \mathrm{c}$ was chromatographed on an ODS seppak cartridge (Waters) with $\mathrm{MeOH}-\mathrm{H}_{2} \mathrm{O}(3: 2)$ to give $2(57.7 \mathrm{mg})$. Fraction $1 \mathrm{~d}$ was chromatographed on an ODS sep-pak cartridge with $\mathrm{MeOH}-\mathrm{H}_{2} \mathrm{O}$ $(3: 2)$, then on an ODS column with $\mathrm{MeOH}-\mathrm{H}_{2} \mathrm{O}(3: 2)$ to give $4(23.0 \mathrm{mg})$ and $6(34.5 \mathrm{mg})$. Fraction 1f was chromatographed on a silica gel (PSQ100B) column with $n$-hexane-acetone $(3: 1)$, then on an ODS sep-pak cartridge with $\mathrm{MeOH}-\mathrm{H}_{2} \mathrm{O}(3: 2)$, followed by HPLC on an ODS column (Develosil ODS, Nomura) with $\mathrm{MeOH}-\mathrm{H}_{2} \mathrm{O}(1: 1)$ to give $1(50.1 \mathrm{mg}), 7$ $(6.9 \mathrm{mg}), \mathbf{8}(4.0 \mathrm{mg})$, and $\mathbf{9}(1.1 \mathrm{mg})$.

GS-1 (1) [Nidulalin A]: Yellow prism (lit. ${ }^{4)}$ orange prism), $[\alpha]_{\mathrm{D}}^{25}-493^{\circ}$ $(c=0.50, \mathrm{MeOH})\left(\right.$ lit. $\left.\left.^{4}\right)-426^{\circ}\left(\mathrm{CHCl}_{3}\right)\right) . \mathrm{CD}(0.0751 \mathrm{~mm}, \mathrm{MeOH}) \Delta \varepsilon(\mathrm{nm})$ : 0 (378), -1.1 (274), -0.045 (243), -0.055 (237), 1.80 (211). The ${ }^{1} \mathrm{H}-$ and ${ }^{13} \mathrm{C}$-NMR spectra in $\mathrm{CDCl}_{3}$ were identical with those of nidulalin $\mathrm{A}^{4}{ }^{4}$ This compound was directly identified by authentic nidulalin $\mathrm{A}^{4)}$ on a TLC plate (silica gel $60 \mathrm{~F}_{254}$, Merck) with $\mathrm{CHCl}_{3}$-acetone (10:1) (Rf: 0.56) and on an HPLC ODS column (Pegasil ODS, Senshu) with $\mathrm{CH}_{3} \mathrm{CN}-\mathrm{H}_{2} \mathrm{O}(1: 1)$ at a flow rate of $0.8 \mathrm{ml} / \mathrm{min}\left(t_{\mathrm{R}}: 8.87 \mathrm{~min}\right)$.

GS-2 (2) [Nidulalin B]: Yellow amorphous powder (lit. ${ }^{4)}$ colorless needles), HR-FAB-MS $m / z 302.0773$ (Calcd for $\mathrm{C}_{16} \mathrm{H}_{14} \mathrm{O}_{6}\left(\mathrm{M}^{+}\right)$: 302.0790). The ${ }^{1} \mathrm{H}$ - and ${ }^{13} \mathrm{C}$-NMR data in $\mathrm{CDCl}_{3}$ were identical with those of nidulalin $\mathrm{B}^{4)}$

GS-3 (3) [1-Hydroxy-3-methylxanthone]: Yellow powder (lit. ${ }^{5)}$ yellow needles), HR-FAB-MS $m / z 226.0621$ (Calcd for $\mathrm{C}_{14} \mathrm{H}_{10} \mathrm{O}_{3}\left(\mathrm{M}^{+}\right)$: 226.0630). The ${ }^{1} \mathrm{H}$ - and ${ }^{13} \mathrm{C}$-NMR spectra in $\mathrm{CDCl}_{3}$ were identical with those of 1-hydroxy-3-methylxanthone from G. micropertusa. ${ }^{5}$

GS-4 (4) $\left[(4 R, 4 \mathrm{a} S, 9 \mathrm{a} R)-1,9 \mathrm{a}-\right.$ Dihydronidulalin A]: White powder (lit. ${ }^{5)}$ white amorphous solid), $\mathrm{mp} 145^{\circ} \mathrm{C}$ from EtOH (lit. $\left.{ }^{5)} 144-146^{\circ} \mathrm{C}\right),[\alpha]_{\mathrm{D}}^{25}$ $-347.2^{\circ}(c=0.83, \mathrm{MeOH})\left(\right.$ lit. $\left.^{5)}-431^{\circ}(\mathrm{MeOH})\right)$, HR-FAB-MS $m / z 305.1030$ (Calcd for $\mathrm{C}_{16} \mathrm{H}_{17} \mathrm{O}_{6}\left[(\mathrm{M}+\mathrm{H})^{+}\right]$: 305.1025$)$ (lit. $\left.\left.{ }^{5}\right) 305.1041\right)$. $\mathrm{CD}(0.495 \mathrm{~mm}$, MeOH) $\Delta \varepsilon(\mathrm{nm}):+0.67(378),-6.77$ (279), +0.019 (243), -0.20 (237), +12.3 (211). The ${ }^{1} \mathrm{H}$ - and ${ }^{13} \mathrm{C}$-NMR spectra in $\mathrm{CDCl}_{3}$ (see Table 1) were identical with those of 1,9a-dihydronidulalin A from G. micropertusa. ${ }^{5}$ )

GS-5 (5) [Sordarial]: Pale yellow needles (lit. ${ }^{7)}$ pale yellow needles), mp $90.5^{\circ} \mathrm{C}$ (lit. $\left.{ }^{7)} 90.5-92.0^{\circ} \mathrm{C}\right) .[\alpha]_{\mathrm{D}}^{25}+22^{\circ}(c=0.37, \mathrm{MeOH})\left(\right.$ lit. $^{7}{ }^{7}+22^{\circ}$ $(\mathrm{MeOH})$ ). The ${ }^{1} \mathrm{H}$ - and ${ }^{13} \mathrm{C}-\mathrm{NMR}$ spectra in $\mathrm{CD}_{3} \mathrm{OD}$ were identical with those of sordarial from $G$. heterospora and G. longispora. ${ }^{7}$

EQ-4 (6) [Microperfuranone]: Colorless plates (lit. ${ }^{5)}$ colorless plates), $[\alpha]_{\mathrm{D}}^{25}$ $\pm 0^{\circ}(c=1.48, \mathrm{MeOH})\left(\right.$ lit. $\left.\left.^{5}\right)-6.8^{\circ}(\mathrm{MeOH})\right)$, HR-FAB-MS $m / z$ 267.1001 (Calcd for $\mathrm{C}_{17} \mathrm{H}_{15} \mathrm{O}_{3}\left[(\mathrm{M}+\mathrm{H})^{+}\right]$: 267.1021) (lit. ${ }^{5)}$ 267.1011). The ${ }^{1} \mathrm{H}-$ and ${ }^{13} \mathrm{C}-$ NMR spectra in $\mathrm{CDCl}_{3}$ were identical with authentic microperfuranone. ${ }^{5}$

EQ-6 (7) [Pinselin]: Yellow powder (lit. ${ }^{8)}$ yellow prism), HR-FAB-MS $m / z 300.0644$ (Calcd for $\mathrm{C}_{16} \mathrm{H}_{12} \mathrm{O}_{6}\left(\mathrm{M}^{+}\right)$: 300.0634). The ${ }^{1} \mathrm{H}-\mathrm{NMR}$ spectrum in acetone- $d_{6}$ was identical with that of pinselin isolated from T. bacillosporus. ${ }^{8)}$ This compound was directly identified with authentic pinselin on a TLC plate (silica gel $60 \mathrm{~F}_{254}$, Merck) with $n$-hexane-acetone $(1: 1)$ (Rf: 0.40).

EQ-7 (8) $[(4 S, 4 \mathrm{a} R, 9 \mathrm{a} R)$-4a-Carbomethoxy-1,4,4a,9a-tetrahydro-4,8-dihydroxy-6-methylxanthone]: White powder, $[\alpha]_{\mathrm{D}}^{25}+31.4^{\circ}(c=0.087, \mathrm{MeOH})$, HR-FAB-MS $m / z 305.1000$ (Calcd for $\mathrm{C}_{16} \mathrm{H}_{17} \mathrm{O}_{6}\left[(\mathrm{M}+\mathrm{H})^{+}\right]$: 305.1025). UV $\lambda_{\max }^{\mathrm{MeOH}} \mathrm{nm}(\log \varepsilon): 280$ (4.77), 348 (4.17). IR $v_{\max }^{\mathrm{KBr}} \mathrm{cm}^{-1}: 3477,2918,1729$, $1646,1560,1458,1362,1281,1200,1083$. CD $(0.131 \mathrm{~mm}, \mathrm{MeOH}) \Delta \varepsilon$ $(\mathrm{nm}):-1.84(314),+8.64(278),-6.20(238),+44.2(220),+28.0(211)$, $+61.9(205)$.

EQ-8 (9) [9-Hydroxymicroperfuranone]: White powder, $[\alpha]_{\mathrm{D}}^{25} \pm 0^{\circ}(c=$ 0.030, MeOH), HR-FAB-MS $m / z 283.0964$ (Calcd for $\mathrm{C}_{17} \mathrm{H}_{15} \mathrm{O}_{4}\left[(\mathrm{M}+\mathrm{H})^{+}\right]$ 283.0971). UV $\lambda_{\max }^{\mathrm{MeOH}} \mathrm{nm}(\log \varepsilon): 281$ (3.73). IR $v_{\max }^{\mathrm{KBr}} \mathrm{cm}^{-1}: 3448,2912$, 1736, 1655, 1560, 1509, 1458.

Hydrogenation of GS-1 (1) A solution of $1(3.0 \mathrm{mg})$ and $\mathrm{NaBH}_{4}$ $(3.0 \mathrm{mg})$ in $\mathrm{EtOH}(1.0 \mathrm{ml})$ was stirred at room temperature for $1 \mathrm{~min}$ to give a product mixture. The product mixture was purified by preparative TLC on silica gel plates (silica gel 60, Merck) with $\mathrm{CHCl}_{3}$-acetone $(9: 1)$ to give a product $(2.5 \mathrm{mg})$, which was identical with 4 by the ${ }^{1} \mathrm{H}$ - and ${ }^{13} \mathrm{C}-\mathrm{NMR}$ spectra in $\mathrm{CDCl}_{3}$ and the $\mathrm{CD}$ spectra in $\mathrm{MeOH}$.

Methylation of EQ-6 (7) A $10 \%$ solution of $\left(\mathrm{CH}_{3}\right)_{3} \mathrm{SiCHN}_{2}$ in $n$-hexane $(200 \mu \mathrm{l})$ was added to a solution of $7(0.7 \mathrm{mg})$ in $\mathrm{MeOH}(200 \mu \mathrm{l})$ under ice-cooling to prepare a reaction mixture. The reaction mixture was stirred at $3{ }^{\circ} \mathrm{C}$ for $1 \mathrm{~h}$ to give a product solution, whose solvent was evaporated in vacuo to give a yellow powder $(\mathbf{1 0})(0.7 \mathrm{mg})$.

2-Methoxy Derivative of EQ-6 (10): Yellow powder, ${ }^{1} \mathrm{H}-\mathrm{NMR}, \delta(\mathrm{ppm})$ from TMS in $\mathrm{CDCl}_{3}: 2.41\left(3 \mathrm{H}, \mathrm{s}, \mathrm{CH}_{3}-6\right), 3.90\left(3 \mathrm{H}, \mathrm{s}, \mathrm{COOCH}_{3}-1\right), 4.03$ $\left(3 \mathrm{H}, \mathrm{s}, \mathrm{CH}_{3} \mathrm{O}-2\right), 6.59$ (s, H-7), 6.71 (s, H-5), 7.38 (d, 9.4, H-4), 7.50 (d, 9.4, $\mathrm{H}-3), 12.1$ (s, OH-8).

Formation of $(\boldsymbol{R})$ - and $(\boldsymbol{S})$-MTPA Esters of EQ-7 (8) $\quad(S)$-MTPA chloride $(20 \mu \mathrm{l})$ was added to a solution of $\mathbf{8}(0.7 \mathrm{mg})$ in pyridine $(200 \mu \mathrm{l})$ to prepare a reaction solution. The reaction solution was stirred at room temperature for $24 \mathrm{~h}$ to give a product solution, whose solvent was evaporated in vacuo to give a crude product. The crude product was chromatographed on a silica gel column followed on an ODS sep-pak cartridge to afford a white powder (11) $(0.6 \mathrm{mg})$.

$(R)$-MTPA chloride $(20 \mu \mathrm{l})$ was added to a solution of $\mathbf{8}(0.9 \mathrm{mg})$ in pyridine $(200 \mu \mathrm{l})$ to prepare a reaction solution. The reaction solution was stirred at room temperature for $24 \mathrm{~h}$ to give a product solution, which was treated in the same way as that for the formation of $\mathbf{1 1}$ from $\mathbf{8}$ to afford a white powder (12) $(0.8 \mathrm{mg})$

Acknowledgements We are grateful to Dr. S. Sekita of National Institute of Health Sciences for the gift of authentic sample of nidulalin A, and to Dr. E. Okuyama of Faculty of Pharmaceutical Sciences, Chiba University for the gift of authentic sample of pinselin. We are also grateful to Miss R. Hara of Analysis Center, Chiba University for the HR-FAB-MS measurements.

\section{References and Notes}

1) Fujimoto H., Okamoto Y., Sone E., Maeda S., Akiyama K., Ishibashi M., Chem. Pharm. Bull., 53, 923-929 (2005), and the references cited therein.

2) This strain was deposited earlier at Research Institute for Chemobiodynamics, Chiba University (present name: Research Center for Pathogenic Fungi and Microbial Toxicoses, Chiba University). Now the voucher specimen is also on deposit in our laboratory.

3) Fujimoto H., Kim Y.-P., Sumino M., Nagano J., Okuyama E., Yamazaki M., Yamaguchi K., 40th Symposium on The Chemistry of Natural Products, Fukuoka 1998, Symposium Papers, pp. 425-430 [Chem.Abstr., 131, 53751 (1999)].

4) Kawahara N., Sekita S., Satake M., Udagawa S., Kawai K., Chem. Pharm. Bull., 42, 1720-1723 (1994).

5) Fujimoto H., Satoh Y., Yamaguchi K., Yamazaki M., Chem. Pharm. Bull., 46, 1506-1510 (1998).

6) Bouillant M. L., Bernillon J., Favre-Bonvin J., Salin N., Z. Naturforsch., 44c, 719-723 (1989).

7) Fujimoto H., Sumino M., Nagano J., Natori H., Okuyama E., Yamazaki M., Chem. Pharm. Bull., 47, 71-76 (1999).

8) Yamazaki M., Okuyama E., Chem. Pharm. Bull., 28, 3649-3655 (1980).

9) Sato S., Suga Y., Yoshimura T., Nakagawa R., Tsuji T., Umemura K., Andoh T., Bioorg. Med. Chem. Lett., 9, 2653-2656 (1999).

10) Ohtani I., Kusumi T., Kashman Y., Kakisawa H., J. Am. Chem. Soc., 113, 4092-4096(1991).

11) Pedro M., Cerqueira F., Sousa M. E., Nascimento M. S. J., Pinto M., Bioorg. Med. Chem., 10, 3725-3730 (2002). 